\title{
Hepatocellular carcinoma a retrospective clinico-pathologic and immunohistochemical study of 15 cases
}

\section{Carcinom hepatocelular - studiu retrospectiv clinicopatologic şi imunohistochimic pe 15 cazuri}

\author{
Cristiana Iulia Dumitrescu ${ }^{1}$, Daniela Dumitrescu ${ }^{2 *}$, Daniela Cernea ${ }^{3}$, \\ Corneliu-Cristian Georgescu ${ }^{4 \#}$, Claudiu Margaritescu ${ }^{5}$
}

1. PhD student, University of Medicine and Pharmacy of Craiova

2. Department of Radiology and Medical Imaging, University of Medicine and Pharmacy of Craiova

3. Anesthesia and Intensive Therapy Clinic, Emergency County Hospital Craiova

4. Department of Pharmacology, University of Medicine and Pharmacy of Craiova

5. Department of Pathology, University of Medicine and Pharmacy of Craiova

\begin{abstract}
Hepatocellular carcinoma (HCC) is the fifth most frequently diagnosed cancer worldwide, and the third most frequent oncological cause of death. Being detected at an advanced, non-resectable stage, HCC is associated with a low 5-year survival and poor prognosis. Recently some studies have demonstrated that the prognosis of HCC correlates to various molecular markers. In this view, we have studied here the immunohistochemical reactivity of 15 HCC cases diagnosed in the last three years for some biomarkers with prognostic value such as p53, alpha-fetoprotein (AFP) and CXCR4, in correlation with the major clinicopathological parameters of these patients. In our casuistry the most prevalent architectural pattern was the trabecular (53.4\%), followed by the pseudoglandular pattern (20\%), while the less common diagnosed were the solid and pleomorphic variants. More than $80 \%$ of these tumors were well to moderate differentiated; developed in the six decade, twice more common in men and diagnosed in advance stages (80\% of cases in stages $\geq I I I)$. Markers such as CK18, CK7 and CEA were usefully in order to certify the primary liver origin and the hepatocellular differentiation of these tumors. Moreover, biomarkers as p53, AFP and CXCR4 were positive especially in more advance stages suggesting the possibility of their utilization as prognostic factors and in the therapeutically stratification of such patients.
\end{abstract}

Key words: hepatocellular carcinoma, immunohistochemistry, pleomorphic, pseudoglandular, solid, trabecular.

\section{Rezumat}

La nivel mondial carcinomul hepatocelular reprezintă cel de-al cincilea cel mai frecvent cancer diagnosticat, fiind totodată pe locul trei ca şi rată a mortalității prin cancer. Întrucât este diagnosticat în stadii

*Corresponding author: Daniela Dumitrescu, Assistant Professor, MD, PhD, Department of Radiology and Medical Imagery, University of Medicine and Pharmacy of Craiova, 1 Tabaci Street, 200642 Craiova, Romania. Phone/Fax +40251-502 263, E-mail: daniela.dumitrescu@gmail.com

\# Author with equal contributions with the main authors. 
avansate neoperabile, carcinomul hepatocelular se asociază cu un prognostic prost şi o rată scăzută de supraviețuire la cinci ani. Studii recente au demonstrat că prognosticul carcinomului hepatocelular se corelează cu diverşi markeri moleculari. În acest sens ne-am propus să studiem reactivitatea imunohistochimică a 15 cazuri de carcinom hepatocelular, diagnosticate în ultimii trei ani pentru o serie de biomarkeri cu valoare prognostică aşa cum sunt oncoproteina p53, alfa-fetoproteina (AFP) şi receptorul CXCR4 în corelație cu cei mai importanți parametrii clinico-patologici ai acestor bolnavi. $\hat{I}$ cadrul cazuisticii investigate patternul arhitectural cel mai des observat a fost cel trabecular (53,4\%), urmat de cel pseudoglandular (20\%), în timp ce la polul opus s-au situat variantele solide şi pleomorfice. Mai mult de $80 \%$ dintre aceste tumori au fost bine sau moderat diferențiate, dezvoltându-se în decada a VI-a de viață, de două ori mai frecvent la bărbați şi au fost diagnosticate în stadii avansate de boală (80\% din cazuri în stadii $\geq I I I)$. Markeri de tipul citokeratinelor CK18, CK7 şi a antigenului carcinoembrionar (CEA) au fost utili pentru confirmarea originii primare hepatice a tumorilor şi în diferențierea lor de alte tumori. În plus markerii p53, AFP şi CXCR4 s-au pozitivat în special în stadii avansate sugerând posibilitatea utilizării lor ca şi factori de prognostic, precum şi în stratificarea terapeutică a unor astfel de bolnavi.

Cuvinte cheie: carcinom hepatocelular, imunohistochimie, pleomorfic, pseudoglandular, solid, trabecular.

Received: 23 ${ }^{\text {rd }}$ May 2013; Accepted: $11^{\text {th }}$ September 2013; Published: $9^{\text {th }}$ November 2013.

\section{Introduction}

Hepatocellular carcinoma (HCC) is the fifth most frequently diagnosed cancer worldwide, and the third most frequent oncological cause of death (1). The incidence of liver cancer varies widely according to geographic localization, with the highest values in East and SouthEast Asia and in Middle and Western Africa, and the lowest values in South-Central and Western Asia, as well as in Northern and Eastern Europe (2). The trend of the incidence for the last two decades indicated increasing frequency of HCC in many parts of the world including the United States and Central Europe, possibly due to the obesity epidemic and the rise in hepatitis $\mathrm{C}$ virus (HCV) infection through continued transmission by injection drug users $(3,4)$. In Romania between 1980 and 2004, mortality rates from liver cancer increased from 1.77 to 10.68 (5), most probably due to the highest rates of HCV infection (3.26\%) among all other European countries (6).

Being detected at an advanced, non-resectable stage, HCC is associated with a low 5year survival and poor prognosis. Moreover, the potentially curative treatment is limited and is restricted only for those cases with tumors that are less than $2 \mathrm{~cm}$ in diameter (7). For these reasons it is absolutely necessary to extend the current knowledge regarding the molecular mechanisms of liver carcinogenesis, to discover novel prognostic biomarkers that may assist in deciding the optimum therapeutically approach and help in identifying novel potential targets for therapeutic interventions (8).

In this paper we have reviewed the histopathological aspects of HCC cases diagnosed in our clinic for the past three years, and we have also investigated the prognostic value of alfa-fetoprotein (AFP), CXCR4 and p53 in the study of these human cancers.

\section{Material and methods}

We reviewed the medical records from the Pathology Laboratory of Emergency Clinical County Hospital Craiova 1 and identified 15 patients who had been diagnosed with HCC from 2010 through 2012. The analyzed cases consisted of 3 biopsy specimens (20\%) and 12 necropsy specimens (80\%). As clinical data we noted each patient's age and gender and as pathological parameters we looked for the histopathological variant, histological differentiation degree (well-moderate; poor), tumor size $(\mathrm{T} \leq 2 \mathrm{~cm} ;>2)$, lymph node metastasis $(\mathrm{N})$, and pTNM ( $\mathrm{Ta}$ ble 1). The histopathological variant, histological grade and TNM classification of HCC was es- 
Table 1. The major clinico-pathological features and p53, AFP and CXCR4 reactivity of the investigated HCC

\begin{tabular}{|c|c|c|c|c|c|c|c|c|c|c|}
\hline \multirow{2}{*}{ HCC type (No.) } & \multirow{2}{*}{ Age } & \multirow{2}{*}{ Gender } & \multicolumn{2}{|c|}{ Diff. } & \multirow{2}{*}{$\mathbf{T}$} & \multirow{2}{*}{$\mathbf{N}$} & \multirow{2}{*}{ pTNM } & \multirow{2}{*}{$\mathbf{P 5 3}^{\#}$} & \multirow{2}{*}{$\mathbf{A F P}^{\#}$} & \multirow{2}{*}{$\mathrm{CXCR}^{\#}$} \\
\hline & & & $\mathbf{W}-\mathbf{M}^{*}$ & $\mathbf{P *}$ & & & & & & \\
\hline Trabecular (1) & 55 & $\mathrm{M}$ & + & & $\mathrm{T} 2$ & 0 & II & - & 0 & 0 \\
\hline Trabecular (2) & 57 & $\mathrm{~F}$ & + & & $\mathrm{T} 3 \mathrm{a}$ & 0 & IIIA & + & 3 & 0 \\
\hline Trabecular (3) & 59 & M & + & & T3a & 0 & IIIA & - & 4 & 4 \\
\hline Trabecular (4) & 62 & $\mathrm{M}$ & + & & T3b & 0 & IIIB & + & 4 & 5 \\
\hline Trabecular (5) & 64 & $\mathrm{M}$ & + & & T3b & 0 & IIIB & + & 4 & 3 \\
\hline Trabecular (6) & 56 & $\mathrm{~F}$ & + & & $\mathrm{T} 4$ & 0 & IIIC & - & 5 & 6 \\
\hline Trabecular (7) & 61 & $\mathrm{M}$ & + & & $\mathrm{T} 2$ & 0 & II & - & 0 & 0 \\
\hline Trabecular (8) & 63 & $\mathrm{~F}$ & + & & T3a & N1 & IVA & + & 5 & 5 \\
\hline Pseudoglandular (1) & 59 & $\mathrm{M}$ & + & & $\mathrm{T} 2$ & 0 & II & - & 4 & 0 \\
\hline Pseudoglandular (2) & 62 & $\mathrm{~F}$ & + & & T3a & 0 & IIIA & - & 6 & 3 \\
\hline Pseudoglandular (3) & 58 & $\mathrm{M}$ & + & & T3b & 0 & IIIB & + & 7 & 5 \\
\hline Solid (1) & 59 & $\mathrm{M}$ & + & & T3a & $\mathrm{N} 1$ & IVA & + & 8 & 5 \\
\hline Solid (2) & 61 & $\mathrm{M}$ & & + & $\mathrm{T} 3 \mathrm{a}$ & $\mathrm{N} 1$ & IVA & + & 10 & 5 \\
\hline Pleomorphic (1) & 57 & $\mathrm{~F}$ & & + & T3a & $\mathrm{N} 1$ & IVA & - & 4 & 5 \\
\hline Pleomorphic (2) & 55 & $M$ & & + & T3a & $\mathrm{N} 1$ & IVB & + & 5 & 4 \\
\hline
\end{tabular}

*- tumor degree of differentiation: $\mathrm{W}-\mathrm{M}=$ well to moderate. ${ }^{*}$ - IHC score

tablished using the World Health Organization criteria (9). The study was carried out after approval by the local ethics committee.

Paraffin blocks from these patients were processed by classical histological techniques (HE stain), and for more detailed histopathological investigation they were stained with Masson's trichrome kit (BioOptica, Albedo, Romania - Code 21-010802IC) and Alcian blue pH 2.5-P.A.S. stain (BioOptica, Albedo, Romania - Code W01030799).

To exclude other histopathological variants of liver tumors (for instance cholangiocarcinoma, undifferentiated carcinoma or liver metastases from other extrahepatic primary carcinomas) we run for each investigated cases a panel of four immunohistochemical markers: CK18 (DC10, mouse anti-human, monoclonal, Dako, Redox, Romania, Code M7010), CK7 (OVTL12/30, mouse anti-human, monoclonal, Dako, Redox, Romania, Code M7018), CD34 (QBEnd10, mouse anti-human, monoclonal, Dako, Redox, Romania, Code M7165) and CEA (Poly- clonal Rabbit anti-human, Dako, Redox, Romania, Code A 0115). Also as prognostic markers we evaluated the expression in the HCC specimens of the following antibodies: Alpha-1-Fetoprotein (Polyclonal Rabbit anti-human, Dako, Redox, Romania, Code A 0008), p53 protein (DO-7, mouse anti-human, monoclonal, Dako, Redox, Romania, Code M7001) and CXCR4 (Polyclonal Rabbit anti-human, SDIX, Cheminpress, Romania, Code CAB011447).

The sections were first processed by 20 minutes heat induced epitope retrieval in DakoCytomation Target Retrieval solution (code no. S 1700) for the p53 and CXCR4 markers, and by 10 minutes enzymatic digestion with proteinase $\mathrm{K}$ (Dako, Redox, Romania - Code S3020) for the other antibodies. Next, the endogenous peroxidase activity was blocked with $3 \%$ hydrogen peroxide in PBS for 15 minutes and then the unspecific binding sites were blocked with 5\% BSA/PBS for $1 \mathrm{H}$. The primary antibodies were used at a dilution of 1:30 for CK18, p53 and CD34, 1:50 for CK7, 1:200 for CEA, 1:400 for Alpha-1-Fetoprotein and 
1:1000 for CXCR4, incubating the sections overnight at $4^{\circ} \mathrm{C}$. The reactions were amplified with LSAB2 (Dako, Redox, Romania - Code K0675) and visualized with 3,3'-Diaminobenzidine (DAB) (Dako, Redox, Romania - Code K3468). For counterstaining we used Mayer`s hematoxylin. Negative-control stainings were done by omitting the primary antibodies, and as external positive control were used normal liver biopsy specimens.

For those markers used in the differential diagnosis, the immunostaining assessment was done only qualitatively noting the presence or absence of cancer cells immunoreactivity. For the CEA and CXCR4, we used the immunoreactive score (IRS) of the Remmele and Stegner (1987) which takes into account the intensity and the extent of markers expression (10). The intensity was scores as follows: $0=$ negative, $1=$ weakly, $2=$ moderately, $3=$ strongly. The quantitative assessment aimed to establishment the fraction of positive tumor cells as follows: $0=$ for the absence of reactivity, 1 for $\leq 10 \%$ positive tumor cells, 2 for $11-50 \%$ reactivity, 3 for $51-80 \%$ positive tumor cells and 4 for $81-100 \%$ reactivity. Finally, by multiplying the intensity score with the quantitative score we obtained the IRS of the investigated markers. To differentiate between positive and negative cases we set an IRS threshold at 4 with positive cases having scores greater than 3 .

The immunohistochemical staining of p53 was estimated counting the percentage of positive nuclei per 1,000 tumor cells in the region of the tumor specimen with the greatest density of staining. The percentage of positive cells expressing p53 was categorized as follows, according to the criteria reported previously by Guo et al. (2006) (11): $<10 \%$ (-) and $\geq 10 \%$ (+).

The images were acquired by utilizing a Nikon Eclipse 55i microscope (Nikon, Apidrag, Bucharest) equipped with a 5-megapixel cooled CCD camera and the Image ProPlus AMS7 software (Media Cybernetics Inc., Buckinghamshire, UK). All recorded values were exported and analyzed in Excel (Microsoft Corporation). Categorical data have been grouped in contingency tables and chi-square testings have been performed in order to evaluate their dependence. Statistical significance was deemed for $\mathrm{p}$ values $<0.05$.

\section{Results}

According to the data presented in $\mathrm{Ta}$ ble 1, the majority of HCC developed in the six decade of life (60\% of cases), with an average age of onset at 59.2 years (range: 55-64). In trabecular HCC subtype group the average age of onset was of 59.6 years, while for pleomorphic HCC subtype it was of 56 years. Men developed twice more frequent HCC than females, with a ratio of 2:1. Regarding the disease stage, we noticed that the HCC were most frequently diagnosed in stage III ( 7 cases that represented $66.7 \%$ ) and the solid and pleomorphic HCC subtypes were detected in more advance stages, respectively with a TNM stage IV.

According to the WHO classification criteria (2010), the most encountered histopathological variant of $\mathrm{HCC}$ was the trabecular type with 8 cases $(53.4 \%)$, followed by the pseudoglandular type with 3 cases (20\%) and the least common were the solid and the pleomorphic variants each one diagnosed in two cases.

In trabecular HCC type, the tumor cells grow in cords of variable thickness that are separated by sinusoid-like blood spaces, immunoreactive to CD34 (Figure 1). The neoplastic cells resembled with hepatocytes, polygonal, displaying an eosinophilic granular cytoplasm, rounded nuclei and prominent nucleoli. According to the degree of differentiation, most tumors were well to moderate differentiated.

Immunohistochemically the neoplastic cells were positive to CK18 and CEA (Figure 2) and negative to CK7. The median onset age was about 60 years, with men being more frequently affected (five from the eight cases) and TNM stage III as the most commonly diagnosed (62.5\%) ( $\mathrm{Ta}$ ble 1). Half of the cases showed cytoplasmic and nuclear positivity for p53 protein, five cases had cytoplasmic positivity for AFP (with score 4 as 


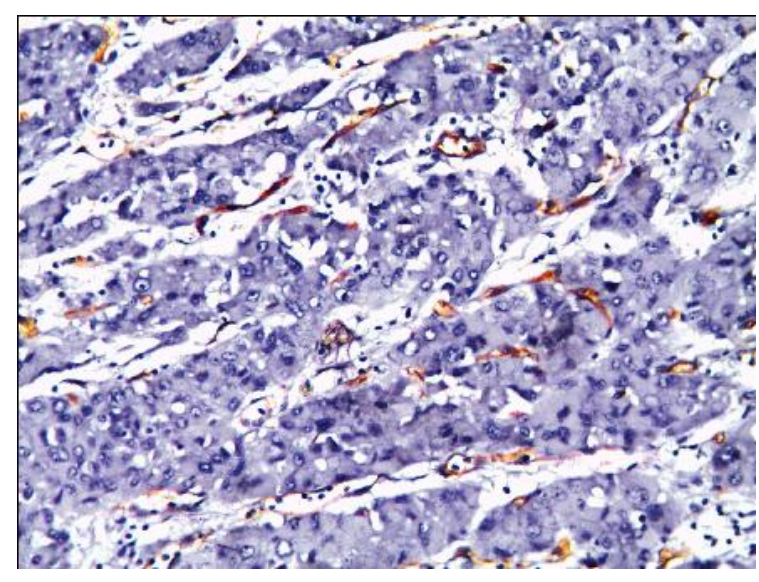

Figure 1. HCC - trabecular type. Sinusoid-like blood spaces, immunoreactive to CD34, x100.

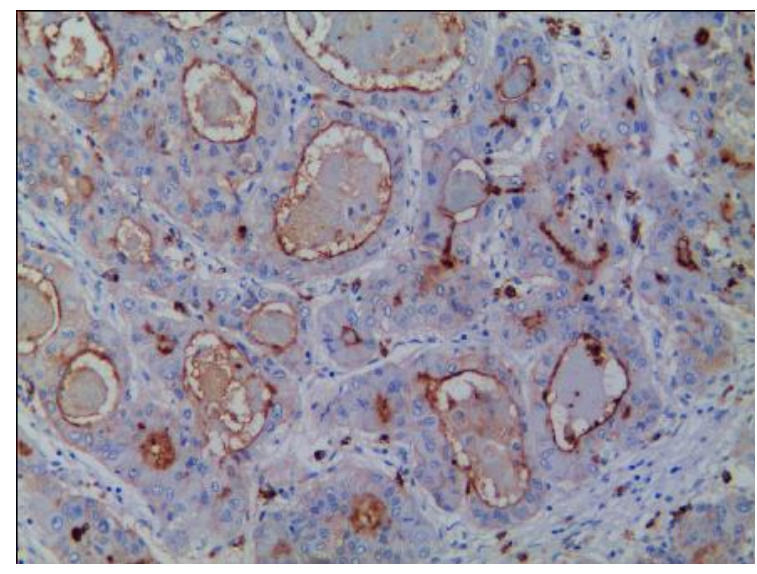

Figure 3. HCC- pseudoglandular type. Neoplastic cells positive to CEA-specific canalicular staining pattern, $\mathrm{x} 100$.

most encountered), and four cases with cytoplasmic and membrane reactivity for CXCR4 (with score 5 in two cases and score 6 in one case).

The pseudoglandular HCC type was diagnosed in three cases from which two were men aged less than 60 years. As for their TNM stage, these cases were grouped in stage III (two cases) and stage II (one case). In this type of HCC, the tumoral pattern consists of gland-like structures mostly formed by a single layer of tumor cells, and some of them are formed by dilatation of the bile

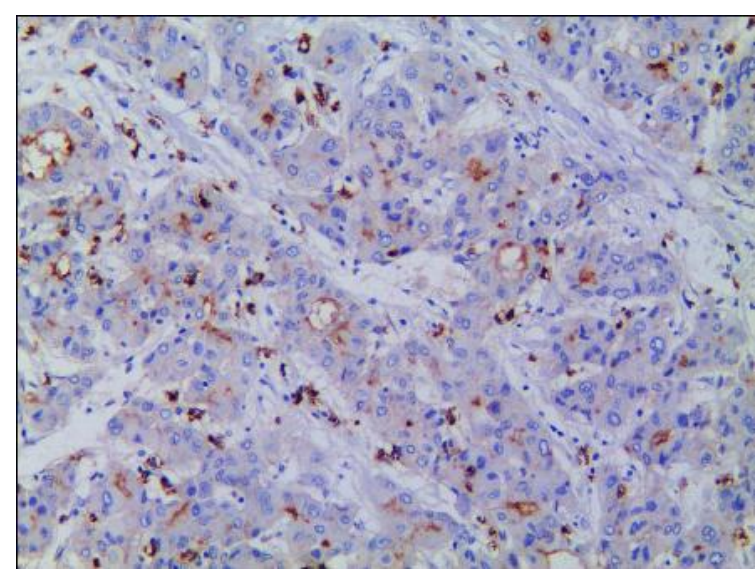

Figure 2. HCC - trabecular type. Neoplastic cells positive to CEA-specific canalicular staining pattern, $\mathrm{x} 100$.

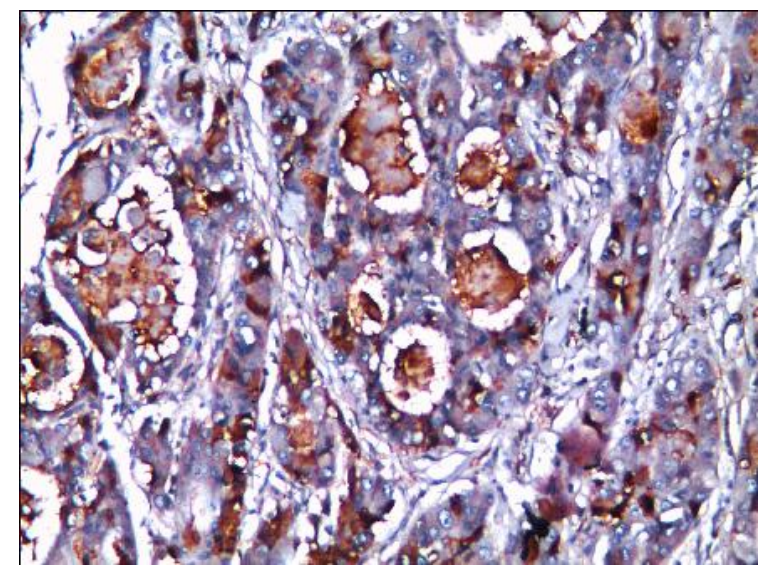

Figure 4. HCC- pseudoglandular type. Neoplastic cells positive to AFP, $\mathrm{x} 100$.

canaliculus-like structures between cancer cells. On PAS- Alcian blue staining, we noticed the presence of proteinaceous fluids PAS+ only in the lumen of pseudoglands. Also, immunohistochemistry revealed a reactivity of the neoplastic epithelium to CK18 and CEA (Figure 3) and to a lesser extent for CK7. p53 reactivity was present in only one case, while for AFP we notice a positive reaction in all investigated cases, the maximum IRH score being 7 (Figure 4). Only in this case the CXCR4 reactivity was obvious in the tumor cells. 


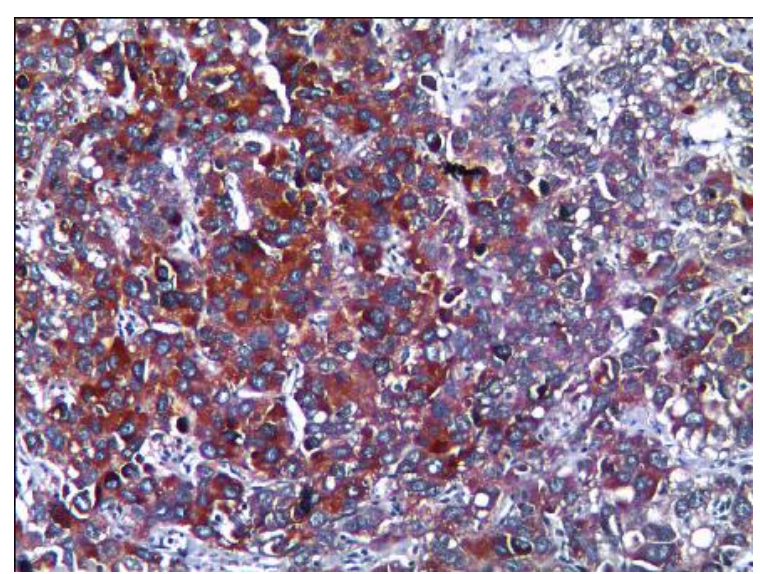

Figure 5. HCC- solid type. High tumor reactivity to AFP, $x 100$.

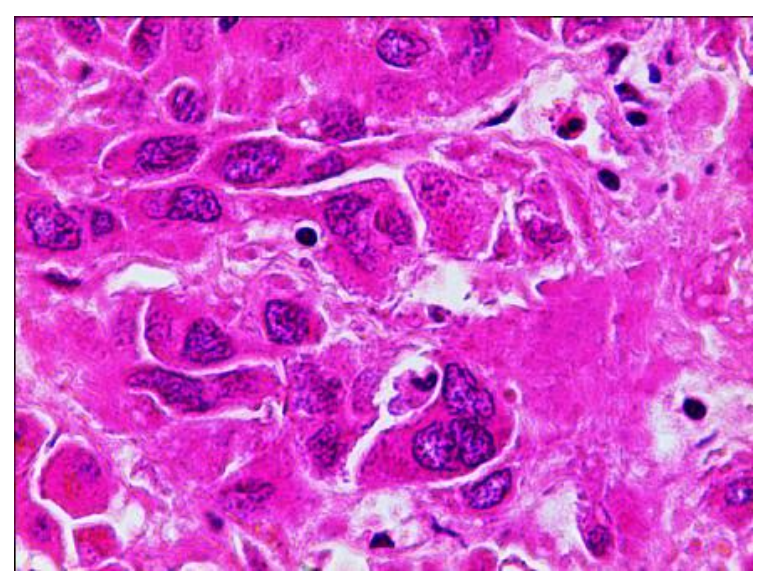

Figure 7. HCC- pleomorphic type. Presence of bizarre multinucleated or mononuclear giant cells. Col HE, x400.

The solid HCC type consists in thick trabeculae compressed into a compact mass with inconspicuous sinusoid-like blood spaces still positive to CD34. Both tumors came from men, one of 59 years and the other of 61 years. The pTNM stage was IVA for both cases. In one case the histological degree was moderate and in the other poor differentiated with neoplastic cells showing an increased nuclear/cytoplasmic ratio and frequent pleomorphism. The neoplastic cells were immunoreactive to CK18 and CEA (predominant with cytoplasmic pattern) and negative

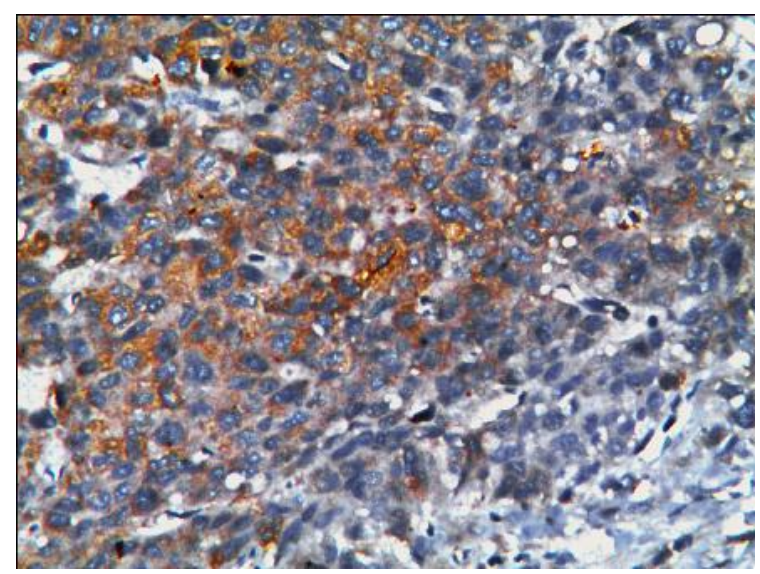

Figure 6. HCC- solid type. Neoplastic cells positive to CXCR4, x200.

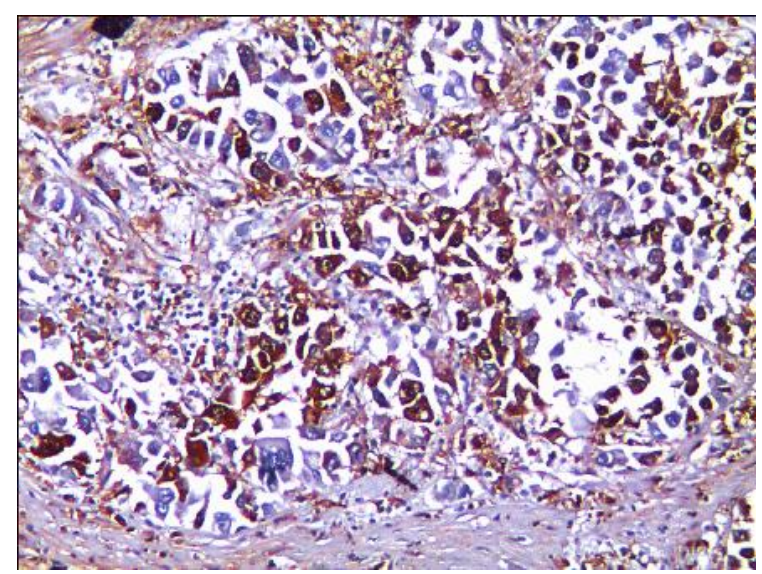

Figure 8. HCC- pleomorphic type. Neoplastic cells positive to AFP, $\mathrm{x} 100$.

to CK7. Also we noticed a high reactivity to p53 protein, to AFP (Figure 5) with high IRS scores (8 and 10) and to CXCR4 (in both cases was recorded as score 5 in IRS scale), (Figure 6).

The pleomorphic HCC type does not shown a distinct trabecular pattern, the neoplastic cells being discohesive and with a marked variation in cellular and nuclear size, shape, and staining. Also we noticed the presence of bizarre multinucleated or mononuclear giant cells (Figure 7). One case was diagnosed in a female of 57 year in stage IVA and the other in a man of 55 
A

\begin{tabular}{l|cc|cc|cc|} 
Advanced tumor (T) & P53 + & P53 - & AFP + & AFP - & CXCR4 + & CXCR4 - \\
\cline { 2 - 7 } Early tumor & 8 & 4 & 11 & 1 & 9 & 3 \\
0 & 3 & 1 & 2 & 0 & 3 \\
\hline
\end{tabular}

\section{Bate stage (TNM) Early stage}

\begin{tabular}{|cc|cc|cc|}
\multicolumn{1}{c}{$\mathrm{p} 53+$} & $\mathrm{p} 53-$ & $\mathrm{AFP}+$ & $\mathrm{AFP}-$ & $\mathrm{CXCR} 4+$ & CXCR4 - \\
\hline 8 & 4 & 11 & 1 & 9 & 3 \\
0 & 3 & 1 & 2 & 0 & 3 \\
\hline
\end{tabular}

Figure 9. Contingency tables grouping the scorings for p53, AFP and CXCR4 for tumor advanced and early stages (A), as well as for TNM early and late stages (B).

years with stage IVB (Table 1). As histological degrees, both cases were poor differentiated tumors. The neoplastic cells were reactive for CK 18 and CEA and negative to CK17. One cases was negative for $\mathrm{p} 53$ protein and both cases were positive to AFP (Figure 8 ) and CXCR4, but with low scores (5 and 4) in IRS scale.

Higher IRS values for p53, AFP and CXCR4 biomarkers were significantly associated with tumors that had more than $2 \mathrm{~cm}$ in their greatest diameter, with vascular invasion or with direct invasion of adjacent organs (tumors with T3 and T4) $(\mathrm{p} 53+, \chi 2(1, \mathrm{~N}=15)=4.285, \mathrm{p}$ $=0.038 ;$ AFP4+, $\chi 2(1, \mathrm{~N}=15)=5.104, \mathrm{p}=$ 0.023 ; CXCR4+, $\chi 2(1, \mathrm{~N}=15)=5.62, \mathrm{p}=$ 0.017), (Figure 9A) and also with tumors diagnosed in more advanced stages ( $\geq$ TNM stage III) $(\mathrm{p} 53+, \chi 2(1, \mathrm{~N}=15)=4.285, \mathrm{p}=0.038 ; \mathrm{AFP}+$, $\chi 2(1, \mathrm{~N}=15)=5.104, \mathrm{p}=0.023 ; \mathrm{CXCR} 4+$, $\chi 2(1, \mathrm{~N}=15)=5.62, \mathrm{p}=0.017),($ Figure $9 B) . \mathrm{In}$ addition, we also noted a statistically significant correlation between AFP and CXCR4 IRS scores in tumors reactive to both markers $(\chi 2(1, \mathrm{~N}=15)$ $=5.625, \mathrm{p}=0.017$ ).

No correlation was found between IRS values for p53, AFP and CXCR4 biomarkers and other morphoclinical parameters (age, gender, lymph node status, degree of histological differentiation and histopathological variants) or between the p53 reactivity and the reactivities for AFP/ CXCR4.

\section{Discussions}

HCC accounts for 85$90 \%$ of all primary liver cancers, with a median survival of less than one year (12). Globally, there are approximately 750,000 new cases of liver cancer reported per year (2). During the past two decades its incidence in the United States has tripled, being considered the fastest increasing cause of cancer-related deaths (13).

HCC is rare before 40 and peaks around the age of 70 , being predominant in males, most likely due to the sex hormones (14). The leading risk factor for HCC is cirrhosis due to chronic hepatitis $\mathrm{B}$ or hepatitis $\mathrm{C}$, followed by obesity, diabetes, and related nonalcoholic fatty liver disease (13).

In our casuistry during the last three years 15 patients were diagnosed with primary HCC. The median age of onset was 59 years (range: 55-64) and men were twice more frequently affected than females. Regarding the disease stage, we noticed that the HCC cases were most frequently diagnosed in stage III (66.7\%) with the solid and pleomorphic HCC subtypes that were detected in more advance stages (stage IV).

The main hallmark of HCC is its resemblance to the normal liver both in its platelike growth and its cytology (9). HCC is usually a hypervascularized tumor showing different degrees of hepatocellular differentiation, ranging from well to poorly differentiated, based upon the architectural and cytologic features. According to the WHO classification criteria (2010) the HCC architectural patterns are: (1) the trabecular (plate-like) with tumor cells that grow in cords of variable thickness that are separated by sinusoid-like blood spaces, (2) pseudoglandular and acinar pattern showing glandlike dilatation of the canaliculi between tumor 
cells (lumens can contain bile), (3) the compact or solid pattern composed of thick trabeculae compressed into a compact mass and (4) scirrhous pattern with marked fibrosis along the sinusoid-like blood spaces with varying degrees of atrophy of tumor trabeculae. As cytological variants there were described: (1) a pleomorphic cells variant (tumor cells presenting marked variation in cellular and nuclear size, shape, and staining), (2) with clear cells (with clear cytoplasm due to the glycogen accumulation), (3) with sarcomatous change (consisting in neoplastic proliferation of spindle cells or bizarre giant cells), (4) fibrolamellar variant with tumor cells growing in sheets that are separated by hyalinized collagen bundles with a characteristic lamellar pattern and (5) undifferentiated variants (9). In our casuistry the most encountered histopathological variant of HCC was the trabecular type (53.4\%), followed by the pseudoglandular variant $(20 \%)$ and the least common were the solid and the pleomorphic variants (each one diagnosed in 13.3\%).

Only on routinely stained sections it is difficult to differentiate metastatic tumors from primary hepatic malignancies. In these cases a panel of immunohistochemical markers comprising CK7, CK20, CEA, CD10, AFP and HepPar1 are really useful (15). Also we must keep in mind that there are many usable markers, but not all of them are equally beneficial, and there is no unique antibodies panel. Thus it becomes more important to carefully select these biomarkers and the interpretation of immunostains must be performed only when taking in the context of other morphological features $(16,17)$. Nearly $75 \%$ of HCC's are CK7-/CK20-, 20\% are $\mathrm{CK} 7+/ \mathrm{CK} 20-$, and $5 \%$ are $\mathrm{CK} 7+/ \mathrm{CK} 20+$ $(18,19)$. A unique feature of HCC among carcinomas is the "capillarization" of sinusoids specifically highlighted by CD34 immunostains $(20,21)$. Also in primary HCC a specific canalicular staining pattern for CEA was reported, but with variable rate of positivity (ranged from 40 to $90 \%)(22,23,24,25,26)$ and in some cases outside the membranous pattern was also observed a cytoplasmic immunoreactivity. In our study all the investigated cases were positive to CK18 and CEA and negative to CK7 with the exception of pseudoglandular variant were we also noticed a weak reactivity to CK7. Together with the typical membranous pattern in more than half of the investigated HCC we also observed a cytoplasmic CEA reactivity.

Typically, HCC is diagnosed late in the course of these diseases, and the overall survival of these patients has not improved over the last 20 years (27). Moreover, the five-year survival rates in the United States have improved modestly to approximately $26 \%$, an improvement that is believed to be associated with improved surveillance in identifiable high-risk patients (i.e., those with hepatitis $B$ and $C$ viruses) and surgical intervention (resection or transplant) for patients with early-stage disease (28). Although the clinical diagnosis and management of early-stage $\mathrm{HCC}$ has improved significantly, HCC prognosis is still extremely poor, which makes it necessary to find new effective and well-tolerated therapy strategies. As in most cancers, HCC pathogenesis is a multistep process, involving sequential events such as chronic inflammation, hyperplasia and dysplasia and ultimately malignant transformation. As a result of a number of epigenetic and genetic alterations that act in time, alterations occur in the molecular pathways responsible for cell proliferation and survival, while other alterations present in almost all tumors involve limitless replicative potential, neoangiogenesis, and insensitivity to antigrowth signals and checkpoint disruption (29). Even though it seems that in HCC there is no dominant pathway specifically altered (29), recent discoveries in the complex networks involved in HCC proliferation, progression and survival have created many opportunities for the development of new targeted therapies.

In this regard many studies demonstrated that the prognosis of $\mathrm{HCC}$ was correlated to some molecular markers (30). One of them is p53 protein that plays a vital role in apoptosis, and it was 
reported to correlate with the prognosis of HCC patients (31). However, in HCC, the prognostic value of p53 is controversial, since several studies show an association of p53 with patients' survival (32-35), while other investigations report no association $(36,37)$. Our investigation revealed a positive p53 immunostain in $53.4 \%$ of the cases, with half of the trabecular cases, two of three pseudoglandular cases and one of the two pleomorphic cases being negative to this marker.

AFP represents the most important biomarker for HCC, especially for the HBV-associated tumor (38) and it is also regarded as an independent factor for the prognosis of HCC (39). Also, the AFP expression is a marker of poor tumor biological behavior, poor liver function and a shorter overall survival time (39-41). Moreover, it was proved that elevated AFP levels were directly associated with more aggressive biological tumor activity (42), poor liver status with hepatitis or chronic cirrhosis (43) and a poor prognosis of HCC (44) for the Asian population. Our immunohistochemical investigation revealed that the AFP reactivity was present in $80 \%$ of the cases but with different intensity in the various HCC variants. The highest IRS scores were recorded in one case of pseudoglandular HCC and in two cases of solid HCC.

A number of studies have shown that CXCR4 is one of the most comprehensive cytokine receptor that plays an important role in the growth and metastasis of a variety of malignant tumors (45). Strictly related to HCC, it was demonstrated that CXCR4 expression may be an independent risk factor for bone metastasis and associated with a poor clinical outcome (46). Moreover it was proved that CXCR4 is an effective curative target for hepatocellular carcinomas with portal vein tumor thrombus (47). In our study, the immunohistochemical expression of CXCR4 was present in $73.4 \%$ of the investigated HCC cases with the highest IRS scores being recorded in 2 cases of trabecular variant, both cases of solid HCC and in one case of pseudoglandular and pleomorphic variant of HCC.
Moreover, we have found that p53, AFP and CXCR4 immunoreactivity was dependent of the more advanced T (T3 and T4) and TNM stages ( $\geq$ stage III) and between AFP and CXCR4 IRS scores was a statistically significant correlation in tumors reactive to both these markers. However given the small number of cases to validate these results further investigations are needed.

\section{Conclusions}

In our casuistry from the last three years we have found 15 cases of HCC that belong to four major histopathological types: trabecular, pseudoglandular, solid and pleomorphic. The prevalent architectural pattern was the trabecular form, and $80 \%$ of the tumors were well to moderate differentiated. Most of the cases developed in the six decade, twice more common in men, and were diagnosed in advanced stages ( $80 \%$ of cases in stages $\geq$ III). An immunohistochemical panel of anti-CK18, CK7 and CEA antibodies was usefully in certifying the primary liver origin and the hepatocellular differentiation of these tumors. Biomarkers such as p53, AFP and CXCR4 were positive especially in more advanced stages suggesting the possibility of their use as prognostic factors and for therapeutically stratification of such patients, but further investigations on more subjects are needed to certify these results.

\section{References}

1. Bosch FX, Ribes J, Cléries R, Díaz M. Epidemiology of hepatocellular carcinoma. Clin Liver Dis. 2005;9:191211.

2. Jemal A, Bray F, Center MM, Ferlay J, Ward E, Forman D. Global cancer statistics. CA Cancer J Clin. 2011;61(2):69-90.

3. Altekruse SF, McGlynn KA, Reichman ME. Hepatocellular carcinoma incidence, mortality, and survival trends in the United States from 1975 to 2005. J Clin Oncol. 2009;27:1485-91.

4. Bosetti C, Levi F, Boffetta P, Lucchini F, Negri E, La Vecchia C. Trends in mortality from hepatocellular carcinoma in Europe, 1980-2004. Hepatology. 2008;48:137-45. 5. Vălean S, Armean P, Resteman S, Nagy G, Mureşan 
A, Mircea PA. Cancer mortality in Romania, 1955-2004. Digestive sites: esophagus, stomach, colon and rectum, pancreas, liver, gallbladder and biliary tree. J. Gastrointestin Liver Dis. 2008;17(1):9-14.

6. Blachier M, Leleu H, Peck-Radosavljevic M, Valla DC, Roudot-Thoraval F. The burden of liver disease in Europe: a review of available epidemiological data. J Hepatol. 2013;58(3):593-608.

7. Llovet JM, Bruix J. Novel advancements in the management of hepatocellular carcinoma in 2008. J Hepatol. 2008;48 Suppl 1: S20-S37.

8. Behne T, Copur MS. Biomarkers for hepatocellular carcinoma. Int J Hepatol. 2012:859076.

9. Bosman FT, Carneiro F, Hruban RH, Theise ND. WHO classification of tumours of the Digestive System 4th edn. IARC Press, Lyon, 2010:322-6.

10. Remmele W, Stegner HE. Recommendation for uniform definition of an immunoreactive score (IRS) for immunohistochemical estrogen receptor detection (ER-ICA) in breast cancer tissue. Pathologe. 1987;8:138-40.

11. Guo RP, Zhong C, Shi M, Zhang CQ, Wei W, Zhang $Y Q$, et al. Clinical value of apoptosis and angiogenesis factors in estimating the prognosis of hepatocellular carcinoma. J Cancer Res Clin Oncol. 2006;132(9):547-55.

12. El-Serag HB, Rudolph KL. Hepatocellular carcinoma: epidemiology and molecular carcinogenesis. Gastroenterology. 2007;132:2557-76.

13. Mittal S, El-Serag HB. Epidemiology of Hepatocellular Carcinoma: Consider the Population. J Clin Gastroenterol. 2013. (Epub ahead of print)

14. Yu MW, Chang HC, Chang SC, Liaw YF, Lin SM, Liu CJ, et al. Role of reproductive factors in hepatocellular carcinoma: Impact on hepatitis B- and C-related risk. Hepatology. 2003;38:1393-400.

15. Abbruzzese JL, Abbruzzese MC, Lenzi R, Hess KR, Raber MN. Analysis of a diagnostic strategy for patients with suspected tumors of unknown origin. J Clin Oncol. 1995;8:2094-103.

16. Burt AD, Portmann BC, Ferrell LD. MacSween's Pathology of the Liver. 5th ed. 2007: 771-87.

17. Lau SK, Prakash S, Geller SA, Alsabeh R. Comparative immunohistochemical profile of hepatocellular carcinoma, cholangiocarcinoma, and metastatic adenocarcinoma. Hum Pathol. 2002;33:1175-81.

18. Johnson DE, Herndier BG, Medeiros LJ, Warnke RA, Rouse RV. The diagnostic utility of the keratin profiles of hepatocellular carcinoma and cholangiocarcinoma. Am J Surg Pathol. 1988;12(3):187-97.

19. Kakar S, Gown AM, Goodman ZD, Ferrell LD. Best practices in diagnostic immunohistochemistry: hepatocellular carcinoma versus metastatic neoplasms. Arch Pathol Lab Med. 2007;131(11):1648-54.

20. Heukamp LC , Fischer HP, Schirmacher P, Chen X, Breuhahn K, Nicolay C, et al. Podocalyxin-like protein 1 expression in primary hepatic tumours and tumour-like lesions. Histopathology. 2006;49(3):242-7.
21. Saad RS, Luckasevic TM, Noga CM, Johnson DR, Silverman JF, Liu YL. Diagnostic value of HepPar1, pCEA, CD10, and CD34 expression in separating hepatocellular carcinoma from metastatic carcinoma in fine-needle aspiration cytology. Diagn Cytopathol. 2004;30(1):16.

22. Balaton AJ, Nehama-Sibony M, Gotheil C, Callard P, Baviera EE. Distinction between hepatocellular carcinoma, cholangiocarcinoma, and metastatic carcinoma based on immunohistochemical staining for carcinoembryonic antigen and for cytokeratin 19 on paraffin sections. J Pathol. 1988;156(4):305-10.

23. Bonetti F, Chilosi M, Pisa R, Novelli P, Zamboni G, Menestrina F. Epithelial membrane antigen expression in cholangiocarcinoma. An useful immunohistochemical tool for differential diagnosis with hepatocarcinoma. Virchows Arch A Pathol Anat Histopathol. 1983;401:307-13.

24. Chu PG, Ishizawa S, Wu E, Weiss LM. Hepatocyte antigen as a marker of hepatocellular carcinoma: an immunohistochemical comparison to carcinoembryonic antigen, CD10, and alpha-fetoprotein. Am J Surg Pathol. 2002;26(8):978-88.

25. Imoto M, Nishimura D, Fukuda Y, Sugiyama K, Kumada T, Nakano S. Immunohistochemical detection of afetoprotein, carcinoembryonic antigen, and ferritin in formalin-paraffin sections from hepatocellular carcinoma. Am J Gastroenterol. 1985;80(11):902-6.

26. Wee A. Diagnostic utility of immunohistochemistry in hepatocellular carcinoma, its variants and their mimics. Appl Immunohistochem Mol Morphol. 2006;14(3):26672 .

27. El-Serag HB, Mason AC, Key C. Trends in survival of patients with hepatocellular carcinoma between 1977 and 1996 in the United States. Hepatology. 2001;33(1):625 .

28. Simard EP, Ward EM, Siegel R, Jemal A. Cancers with increasing incidence trends in the United States: 1999 through 2008. CA Cancer J Clin. 2012;62:118-28.

29. Llovet JM, Bruix J. Molecular targeted therapies in hepatocellular carcinoma. Hepatology. 2008;48:1312-27.

30. Qin LX, Tang ZY. Recent progress in predictive biomarkers for metastatic recurrence of human hepatocellular carcinoma: a review of the literature J Cancer Res Clin Oncol. 2004;130(9):497-513.

31. Hayashi H, Sugio K, Matsumata T, Adachi E, Takenaka K, Sugimachi K. The clinical signiWcance of p53 gene mutation in hepatocellular carcinoma from Japan. Hepatology. 1995;22(6):1702-7.

32. Naka T, Toyota N, Kaneko T, Kaibara N. Protein expression of $\mathrm{p} 53$, p21WAF1, and $\mathrm{Rb}$ as prognostic indicators in patients with surgically treated hepatocellular carcinoma. Anticancer Res. 1998;18(1B):555-64.

33. Qin LF, Ng IO. Expression of p27(KIP1) and p21(WAF1/CIP1) in primary hepatocellular carcinoma: clinicopathologic correlation and survival analysis. Hum Pathol. 2001;32(8):778-84. 
34. Schöniger-Hekele M, Hänel S, Wrba F, Müller C. Hepatocellular carcinoma--survival and clinical characteristics in relation to various histologic molecular markers in Western patients. Liv Liver Int. 2005;25(1):62-9.

35. Sung CO, Yoo BC, Koh KC, Cho JW, Park CK. Prognostic significance of p53 overexpression after hepatic resection of hepatocellular carcinoma. Korean J Gastroenterol. 2005;45(6):425-30.

36. Terris B, Laurent-Puig P, Belghitti J, Degott C, Hénin D, Fléjou JF. Prognostic influence of clinicopathologic features, DNAploidy, CD44H and p53 expression in a large series of resected hepatocellular carcinoma in France. Int J Cancer. 1997;74(6):614-9.

37. Tseng PL, Tai MH, Huang CC, Wang CC, Lin JW, Hung $\mathrm{CH}$, et al. Overexpression of VEGF is associated with positive p53 immunostaining in hepatocellular carcinoma (HCC) and adverse outcome of HCC patients. J Surg Oncol. 2008 Oct 1;98(5):349-57.

38. Kao WY, Su CW, Chau GY, Lui WY, Wu CW, Wu JC. A comparison of prognosis between patients with hepatitis B and C virus- related hepatocellular carcinoma undergoing resection surgery. World J Surg. 2011;35(4):85867.

39. Zhou J, Yan T, Bi X, Zhao H, Huang Z, Zhang Y, et al. Evaluation of seven different staging systems for alphafetoprotein expression in hepatocellular carcinoma after hepatectomy. Tumour Biol. 2013;34(2):1061-70.

40. Changchien CS, Chen CL, Yen YH, Wang JH, Hu TH, Lee CM, et al. Analysis of 6381 hepatocellular carcinoma patients in southern Taiwan: prognostic features, treatment outcome, and survival. J Gastroenterol. 2008;43(2):159-70.
41. Japan LCSGi. Survey and follow-up study of primary liver cancer in Japan - report 11. Kanzo. 1995;36:208-18.

42. A new prognostic system for hepatocellular carcinoma: a retrospective study of 435 patients: the Cancer of the Liver Italian Program (CLIP) investigators. Hepatology. 1998;28(3):751-5.

43. Hu KQ, Kyulo NL, Lim N, Elhazin B, Hillebrand DJ, Bock T. Clinical significance of elevated alpha-fetoprotein (AFP) in patients with chronic hepatitis $\mathrm{C}$, but not hepatocellular carcinoma. Am J Gastroenterol. 2004;99(5):860-5.

44. Yen YH, Changchien CS, Wang JH, Kee KM, Hung $\mathrm{CH}, \mathrm{Hu} \mathrm{TH}$, et al. A modified TNM-based Japan Integrated Score combined with AFP level may serve as a better staging system for early-stage predominant hepatocellular carcinoma patients. Dig Liver Dis. 2009;41(6):43141.

45. Ueland J, Yuan A, Marlier A, Gallagher AR, Karihaloo A. A novel role for the chemokine receptor cxcr4 in kidney morphogenesis: an in vitro study. Dev Dyn. 2009;238(5):1083-91.

46. Xiang ZL, Zeng ZC, Tang ZY, Fan J, Zhuang PY, Liang Y, et al. Chemokine receptor CXCR4 expression in hepatocellular carcinoma patients increases the risk of bone metastases and poor survival. BMC Cancer. 2009;9:176.

47. Li N, Guo W, Shi J, Xue J, Hu H, Xie D, et al. Expression of the chemokine receptor CXCR4 in human hepatocellular carcinoma and its role in portal vein tumor thrombus. J Exp Clin Cancer Res. 2010;29:156. 